\title{
Ethnobotanical Survey of Medicinal Plants in the Cities of Goianésia And Ipameri, in Goiás, Brazil
}

\author{
Matheus Vinicius Abadia Ventura*1, Estevam Matheus Costa ${ }^{2}$ and Marcio Moacir Bessa ${ }^{2}$ \\ ${ }^{1}$ Goiano Federal Institute, Brazil \\ ${ }^{2}$ Paulista State University, Brazil
}

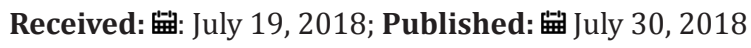

*Corresponding author: Matheus Vinicius Abadia Ventura, Goiano Federal Institute, Rio Verde - GO, Brazil

\begin{abstract}
Medicinal plants include plant species with medicinal properties, which in some cases are used for specific purposes of healing or prevention. Thus, ethnobotanica is the rescue of this traditional knowledge, related to the use of this flora as a resource. The objective of this article was to carry out a bibliographic review, adopting documentary research as a criterion based on articles published in renowned national and international journals specializing in the ethnobotanical aspects of medicinal plants reported in the state of Goiás. Most interviewees responded to use plants for for medicinal purposes, with women being the majority. In addition, leaves are the most used parts for different diseases. The use of medicinal plants is a widely used practice among residents of the cities (Goianésia and Ipameri, Goiás). In general, the species indicated by the inhabitants in the ethnobotanical survey demonstrated the potential for pharmaceutical use, since they presented some compounds known to be important.
\end{abstract}

Keywords: Lamiaceae; Asteraceae; flora; tradition

\section{Introduction}

Brazil presents the greatest biological diversity in the world, possessing a rich flora arousing the interests of scientific communities for study and conservation of these resources [1]. Thus, ethnobotanica is the rescue of this traditional knowledge, related to the use of this flora as a resource [2,3], since man has not lost the close relationship with plants and nature, bringing him individual benefits [4]. The medicinal plants comprise plant species with medicinal property, which in some way is used for specific purposes of cure or prevention [5,6] From surveying in certain communities it is possible to ascertain the vegetation resources and their benefit in several factors, which are transferred from generation to generation [7]. The objective of this article was to carry out a bibliographic review, adopting documentary research as a criterion based on articles published in renowned national and international journals specialized in ethnobotanical aspects of medicinal plants reported in the state of Goiás.

\section{Methodology}

An ethnobotanical bibliographical survey was carried out on reputed pulicated articles that cataloged the species in two important cities in the state of Goiás. The ethnobotanical survey of medicinal plants were carried out through documentary research in the following locations described in Table 1. The informational survey in the city of Ipameri - GO conducted by [8] was conducted in the period from August 2008 to June 2009 where 200 people were interviewed. In the city of Goianésia, the survey period was made from May to June 2013 by [9], where 50 people were interviewed.
Table 1: Locations used in ethnobotanical surveys.

\begin{tabular}{|c|c|c|}
\hline City / State & Sources Author & Location \\
\hline Ipameri - Goiás & Zucchi et al. (2013) & $\begin{array}{l}\text { Latitude: } 17^{\circ} \text { 43' } 19^{\prime \prime} \mathrm{S} \\
\text { Longitude: } 48^{\circ} \text { o9' } 35^{\prime \prime} \mathrm{W}\end{array}$ \\
\hline Goianésia - Goiás & Silva \& Faria (2014) & 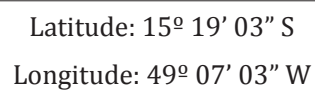 \\
\hline
\end{tabular}

\section{Results and Discussion}

[8] observed in the city of Ipameri, in Goiás, where 200 families were interviewed, 75 of whom stated that they did not use medicinal plants, and the other 125 reported doing so $(54 \%$ female and $46 \%$ female male), representing $62.5 \%$, and Silva \& Faria (2014), observed that in Goianésia - Goiás, 48 of the 50 people interviewed (41 females and 9 males) use plants for medicinal purposes (96\%). According to $[10,11]$ there is a predominance of women with greater use due to greater presence during the day at home in the performance of domestic activities, which was not demonstrated in the work of $[8,12]$, which despite being greater than half, did not present a significant superiority [13] observed that $70 \%$ of the interviewees were female.

In both, the surveys cited the species used by the interviewees for medicinal purposes, totaled 61 species in 23 families as shown in Table 2, and the popular names, the medicinal use and the part of the plant used were also described. In the city of Ipameri - Goiás, in the survey of [8], the species that have stood out because they are the most used are quebra-pedra (Phyllanthus 
niruri L.), camomila (Chamomilla recutita (L.) Rauschert.), hortelãrasteira (Mentha x villosa L.), poejo (Mentha pulegium L.), funcho (Foeniculum vulgare Mill.), babosa (Aloe vera L.) malva (Althaea officinalis L.), guaco (Mikania glomerata Spreng.), mentrasto (Ageratum conyzoides L.), alfavacão (Ocimum gratissimum L.), losna (Artemisia canphorata Vill.), bálsamo (Eysenhardtia platycarpa Mich.), carqueja (Baccharis trimera (Less.) DC.), boldosete-dores (Plectranthus barbatus Andrews.), and capim-cidreira (Cymbopogon citratus (DC.) Stapf.)

Table 2: Plants used for medicinal purposes identified in the cities of Goianésia - GO and Ipameri - GO.

\begin{tabular}{|c|c|c|c|}
\hline Family / Scientific Name & $\begin{array}{l}\text { Name } \\
\text { Common }\end{array}$ & Use & Used Part of Plant \\
\hline \multicolumn{4}{|l|}{ Acanthaceae } \\
\hline Justicia pectoralis Jacq. & Anador de folha & Headache & leaf \\
\hline \multicolumn{4}{|l|}{ Adoxaceae } \\
\hline Sambucus australis Cham. \& Schldl. & Sabugueiro & General pain, fever and the flu; Measles & leaf e flower \\
\hline \multicolumn{4}{|l|}{ Alliaceae } \\
\hline Allium cepa L. & Cebola branca & The flu & stalk \\
\hline \multicolumn{4}{|l|}{ Amaranthaceae } \\
\hline $\begin{array}{l}\text { Alternanthera dentata (Moench.) } \\
\text { Stuchlik }\end{array}$ & Terramicina & External wounds, flu, eye inflammation & leaf \\
\hline Chenopodium ambrosioides L. & Erva-de-santa-maria & Inflammation in general; Broken bone; Worms & leaf \\
\hline \multicolumn{4}{|l|}{ Annonaceae } \\
\hline $\begin{array}{l}\text { Duguetia furfuracea (St. Hil.) Benth } \\
\text { \& Hook. F. }\end{array}$ & Sofre-dos-rins-quem -quer & Kidney problems & leaf \\
\hline \multicolumn{4}{|l|}{ Apiaceae } \\
\hline Coriandrum sativum L. & Coentro & Stomach ache Soothing and insomnia & leaf \\
\hline Pimpinella anisum L. & Erva doce & Depression; Gases and colic & leaf, flower e seed \\
\hline Foeniculum vulgare Mill. & Funcho & Soothing and insomnia; Gases, flu and cold & leaf \\
\hline Petroselinum crispum (Mill.) Fuss & Salsa & $\begin{array}{l}\text { Gases, flu and cold } \\
\text { Infection of uterus }\end{array}$ & root \\
\hline \multicolumn{4}{|l|}{ Asphodelaceae } \\
\hline Aloe vera L. & Babosa & $\begin{array}{l}\text { Healing; Weight loss; intestine arrested; } \\
\text { Hemorrhoid problem; Hair Treatment }\end{array}$ & leaf \\
\hline \multicolumn{4}{|l|}{ Asteraceae } \\
\hline Ageratum conyzoides L. & Mentrasto & $\begin{array}{l}\text { Soothing and insomnia; menstrual cramps; } \\
\text { Depression; Pain in general (children); Pain in } \\
\text { the stomach and gas; Labyrinthitis }\end{array}$ & leaf \\
\hline Artemisia canphorata Vill. & Losma & Stomach problems & leaf \\
\hline Artemisia vulgaris L. & Artimigio & Headaches; The flu & leaf \\
\hline Baccharis trimera (Less.) D.C. & Carqueja & Diabetes & leaf \\
\hline $\begin{array}{c}\text { Chamomilla recutita (L.) Rauschert } \\
\text { Coreopsis grandiflora Hogg ex } \\
\text { Sweet }\end{array}$ & Camomila & Soothing and insomnia; Depression & leaf \\
\hline \multirow[t]{2}{*}{ Egletes viscosa (L.) Less } & Marcelinha & Diarrhea and intestinal fever & leaf \\
\hline & & Flu, cough, hoarseness, throat infection & leaf \\
\hline Mikania glomerata Spreng. & Guaco & $\begin{array}{c}\text { bronchitis, allergies, skin infections and } \\
\text { rheumatism }\end{array}$ & \\
\hline Solidago chilensis Meyen & Arnica & Healing and Menstrual Cramps & leaf \\
\hline Vernonia condensata Baker & Boldo & Pain in the stomach and liver & leaf \\
\hline Vernonia polyanthes Less & Assa-peixe & Bronchitis and flu & leaf \\
\hline \multicolumn{4}{|l|}{ Brassicaceae } \\
\hline Nasturtium officinale R. Br. & Agrião & Flu and cough & leaf \\
\hline \multicolumn{4}{|l|}{ Costaceae } \\
\hline Costus spicatus (Jacq.) Sw. & Cana de macaco & Kidney problems & stalk e leaf \\
\hline
\end{tabular}




\begin{tabular}{|c|c|c|c|}
\hline Crassulaceae & & & \\
\hline Cotyledon orbiculata L. & Bálsamo & Stomach pain and gastritis & leaf \\
\hline Kalanchoe brasiliensis Cambess & Folha santa & Flu and cold & leaf \\
\hline \multicolumn{4}{|l|}{ Fabaceae } \\
\hline Myroxylon peruiferum L. f. & Bálsamo & Stomach pain and gastritis & leaf \\
\hline $\begin{array}{l}\text { Stryphnodendron adstringens } \\
\text { (Mart.) Coville }\end{array}$ & Barbatimão & Stomach ache; Uterus and vaginal infection & stalk e leaf \\
\hline $\begin{array}{c}\text { Andira inermis (W. Wright) Kunth } \\
\text { ex DC. }\end{array}$ & Quina & Anemia & stalk \\
\hline Pterodon emarginatus Vogel & Sucupira & Sore throat & leaf \\
\hline \multicolumn{4}{|l|}{ Lamiaceae } \\
\hline Lavandula angustifolia Mill. & Alfazema & $\begin{array}{l}\text { Anxiety and restlessness, blood pressure, } \\
\text { fever, scarring of thrush, heartbeat, migraine } \\
\text { pain, relaxation, improve sleep quality, stress } \\
\text { and depression }\end{array}$ & flower \\
\hline Melissa officinalis L. & Erva-cidreira & Soothing; Flu and cold & leaf e root \\
\hline Mentha arvensis L. & Vique & Flu Soothing and insomnia; & leaf \\
\hline Mentha pulegium L. & Poejo & Stomach ache; Flu and cold & \\
\hline Mentha viridis L. & Alevante & The flu; Calming and insomnia & leaf \\
\hline Mentha x villosa Huds & Hortelãzinho & $\begin{array}{l}\text { Flu, cold, fever and bronchitis; Indigestion; } \\
\text { Worms }\end{array}$ & leaf \\
\hline Ocimum gratissimum L. & Alfavacão & $\begin{array}{l}\text { Soothing; urine infection; Gases; flu, cold, } \\
\text { hoarseness and bronchitis }\end{array}$ & leaf \\
\hline Ocimum tenuiflorum $\mathrm{L}$. & Manjericão & Flu & leaf \\
\hline $\begin{array}{l}\text { Plectranthus amboinicus (Lour.) } \\
\text { Spreng. }\end{array}$ & Hortelã-da-folha-gorda & $\begin{array}{c}\text { Flu and cold; Problems in the stomach and } \\
\text { vomiting }\end{array}$ & leaf \\
\hline Plectranthus barbatus Andrews. & Boldo-sete-dores & Headache & leaf \\
\hline Rosmarinus officinalis L. & Alecrim & $\begin{array}{l}\text { Flu, shortness of breath, sinusitis; Heart } \\
\text { problems; Calming and insomnia }\end{array}$ & leaf \\
\hline Salvia officinalis $L$ & Sálvia & $\begin{array}{l}\text { Relief of canker sores, bronchitis, dandruff, } \\
\text { phlegm, gingivitis, rheumatism, vomiting, } \\
\text { cough, diarrhea, diabetes, indigestion }\end{array}$ & leaf \\
\hline \multicolumn{4}{|l|}{ Lauraceae } \\
\hline Cinnamomum canphora Turra & Cânfora & Muscle or skin problems & leaf \\
\hline Cinnamomum zeylanicum Breyn & Canela & Soothing & leaf \\
\hline Persea americana Mill. & Abacate & Kidney problems & leaf \\
\hline Punica granatum L. & Romã & Throat and urine infection & leaf e fruit \\
\hline \multicolumn{4}{|l|}{ Malvaceae } \\
\hline Gossypium hirsutum L. & Algodão & $\begin{array}{l}\text { Infection and inflammation in general; } \\
\text { Infection in the uterus and vagina; Associated } \\
\text { Issues }\end{array}$ & leaf e root \\
\hline Malva parviflora $\mathrm{L}$. & Malva & Flu, cold, gastritis, skin sores & leaf e flower \\
\hline Waltheria indica L. & Douradinha & Kidney problems & leaf \\
\hline \multicolumn{4}{|l|}{ Phyllanthaceae } \\
\hline Phyllanthus niruri L. & Quebra-pedra & Kidney problems & root \\
\hline \multicolumn{4}{|l|}{ Phytolaccaceae } \\
\hline Petiveria alliacea L. & Guiné & Sinusitis & leaf \\
\hline \multicolumn{4}{|l|}{ Plantaginaceae } \\
\hline Plantago major L. & Tanchagem & Infection (inflammation) in general & leaf \\
\hline \multicolumn{4}{|l|}{ Poaceae } \\
\hline Cymbopogon citratus (DC.) Stapf. & Capim-cidreira & $\begin{array}{l}\text { Colic; Soothing and insomnia; Headaches and } \\
\text { in the body; Influenza and cold; High pressure }\end{array}$ & leaf \\
\hline
\end{tabular}




\begin{tabular}{|c|c|c|c|}
\hline Rubiaceae & & Diabetes & \\
\hline Morinda citrifolia L. & Noni & The flu \\
\hline Rutaceae & Limão & fruit \\
\hline Citrus limon L. & Arruda & menstrual cramps; Flu, cold and sinusitis & Fruit \\
\hline Ruta graveolens L. & Erva cidreira & Soothing; Flu and cold & leaf \\
\hline Verbenaceae & Pau terra & Toothache (when the baby's teeth are born) & root \\
\hline Lippia alba (Mill.) N.E. Br. & Açafrão & $\begin{array}{c}\text { Arthritis, osteoarthritis and other } \\
\text { inflammatory diseases, gastrointestinal } \\
\text { problems, fever, treat colds }\end{array}$ & The flu \\
\hline Vochysiaceae & Gengibre & root \\
\hline Zingiberaceae & leaf e root \\
\hline
\end{tabular}

[9] in Goianésia - Goiás, reported that the five medicinal species most used by the residents were hortelã da folha gorda (Plectranthus amboinicus (Lour.) Spreng.), alecrim (Rosmarinus officinalis L.), hortelãzinho (Mentha x villosa Huds), boldo (Vernonia condensata Baker) and capim cidreira (Cymbopogon citratus (DC) Stapf.), Among the 61 species mentioned within the 23 families, the family that includes the largest number of species is Lamiaceae (12 species) and Asteraceae (11 species). Souza \& Felfili (2006) observed in their work in the city of Alto Paraiso in Goiás, that the predominant families were Fabaceae (12 species) and Asteraceae (14 species). It is necessary to reinforce that the work of [8] (8 species) and Lamiaceae (10 species) were the predominant species. With this, we observe the diversity of species within the state of Goiás. Of the 61 species described and raised, the most frequently used plant parts were leafy leaves, as described (Table 3 ). The leaves were also the most cited among those interviewed in the works of $[4,14]$. Of the 61 species raised, the use of medicinal plants, according to the interviewees, has the purpose, mostly to cure pain and flu. The same result was also found for [11,14], where most of the interviewees cited species to cure influenza, fever and pain.

Table 3: Parts of the plant most used in production for medicinal purposes.

\begin{tabular}{|c|c|}
\hline Parts of the Plant & Number of Species \\
\hline Sheets & $50(72,46 \%)$ \\
\hline Fruits & $3(4,34 \%)$ \\
\hline Flower & $4(5,80 \%)$ \\
\hline Stalk & $4(5,80 \%)$ \\
\hline Root & $7(10,14 \%)$ \\
\hline Seeds & $1(1,46 \%)$ \\
\hline Total & $69(100 \%)$ \\
\hline
\end{tabular}

\section{Conclusion}

The use of medicinal plants is a widely used practice among city dwellers (Goianésia and Ipameri, Goiás), although not all the inhabitants cultivate the plants, they did not abandon the practice of using them, acquiring them when necessary, by means of relatives and neighbors. In general, the species indicated by the inhabitants in the ethnobotanical survey demonstrated the potential for the pharmaceutical use, since they demonstrate some compounds that are recognized as important, in addition, the use is independent of the sex and extends to diverse age groups and socioeconomic, representing an alternative to the consumer market. But anatomical and pharmacological studies of these plants are suggested to give greater reliability.

\section{References}

1. Souza CDD, Felfili JM (2006) The utilization of medicinal plants in the region of Alto Paraíso of Goiás, GO, Brazil. Acta Botanica Brasilica 20(1): 135-142.

2. Amorozo MCM (1996) Abordagem etnobotânica na pesquisa de plantas medicinais. Plantas medicinais: arte e ciência - um guia de estudo interdisciplinar. São Paulo: Ed UNESP.

3. Begossi A (1998) Etnobotânica em comunidades caiçaras. Etnobotânica: bases para a conservação. Rio de Janeiro: EDUR.

4. Souza MD, Fernandes RR, Pasa MC (2010) Estudo etnobotânico de plantas medicinais na comunidade São Gonçalo Beira Rio, Cuiabá, MT. Biodiversidade 9(1): 91-100.

5. Amorozo MCM, Gély AL (1988) Uso de plantas medicinais por caboclos do baixo Amazonas, Barcarena, PA, Brasil. Boletim do Museu Paraense Emílio Goeldi, Série Botânica 4(1): 1-4.

6. Silva JS, de Carvalho JNF, Teixeira WS, Franco ÍO, Ribeiro DD (2010b) 088-Importância do uso de plantas medicinais em comunidades rurais no sudoeste de Goiás. Cadernos de Agroecologia 5(1).

7. Silva CG, Marinho MGV, Lucena MFA, Costa JGM (2015) Ethnobotanical survey of medicinal plants in the caatinga area in the community of sitio nazaré, milagres, ceará, Brazil. Revista Brasileira de Plantas Medicinais 17(1): 133-142.

8. Zucchi MR, Oliveira Júnior VF, Gussoni MA, Silva MB, Silva FC, et al. (2013) Ethnobotanical survey of medicinal plants in Ipameri City-Goiás State. Revista Brasileira de Plantas Medicinais 15(2): 273-279.

9. Silva RD, Faria MT (2014) Caracterização e etnobotânica e histoquímica de plantas medicinais utilizadas pelos moradores do Bairro Carrilho, Goianésia (GO). Enciclopédia Biosfera, Centro Científico ConhecerGoiânia 10(19): 2807-2829.

10. Ricardo LGPS (2011) Estudos etnobotânicos e prospecção fitoquímica das plantas medicinais utilizadas na comunidade do Horto, Juazeiro do Norte (CE). (Dissertação de mestrado - Centro de Saúde e Tecnologia Rural, Universidade Federal de Campina Grande). 
11. Badke MR, Budó MDLD, Silva FMD, Ressel LB (2011) Medicinal plants: the knowledge sustained by daily life practice. Escola Anna Nery 15(1): 132-139.

12. Silva MABD, Melo LVL, Ribeiro RV, Souza JPMD, Lima JCS, et al. (2010a) Ethnobotanical survey of plants used as anti-hyperlipidemic and anorexigenic by the population of Nova Xavantina-MT, Brazil. Revista Brasileira de Farmacognosia 20(4): 549-562.

ISSN: 2574-1241

DOI: 10.26717/BJSTR.2018.07.001500

Matheus Vinicius Abadia Ventura. Biomed J Sci \& Tech Res

(C) This work is licensed under Creative

Submission Link: https://biomedres.us/submit-manuscript.php
13. Cruz EAL, Silva JWS, Garcia WM, Ferraz-Neto É, Silva Nunes JR, et al. (2011) Perfil e Utilização de Plantas Medicinais em quintais da comunidade de Salobra Grande distrito de Porto Estrela-MT. Uniciências 15(1): 53-66.

14. Lima RA, Magalhães SA, dos Santos MRA (2011) Levantamento etnobotânico de plantas medicinais utilizadas na cidade de Vilhena, Rondônia / Ethnobotanical survey of medicinal plants used in the city of Vilhena, Rondônia. Revista Pesquisa \& Criação 10(2): 165-179.

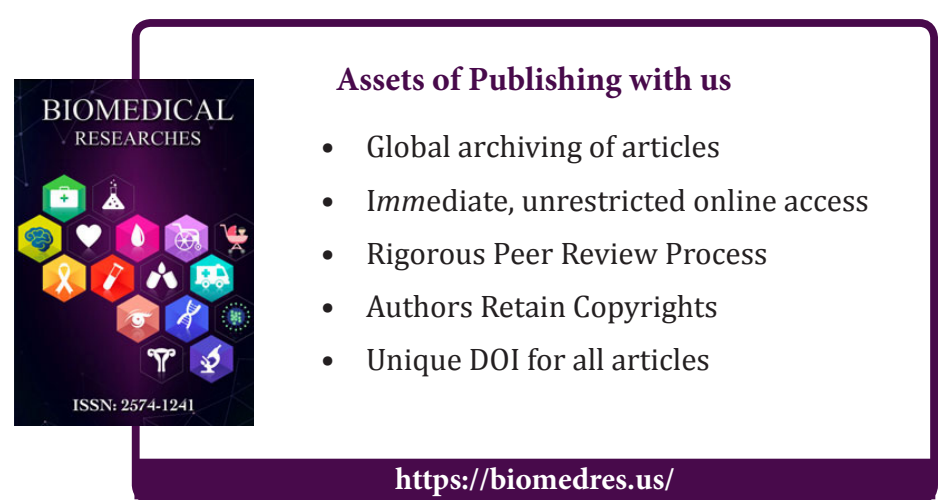

